\title{
Evaluation of the Services Provided to Children With Cerebral Palsy From the Guardians' Perspective
}

\author{
Osama Al-Smadi (Corresponding author) \\ Al-Imam Mohammad Ibn Saud Islamic University, Saudi Arabia
}

Received: January 8, 2019 Accepted: March 2, 2019 Published: March 5, 2019

doi: 10.5296/ire.v7i1.14207

URL: https://doi.org/10.5296/ire.v7i1.14207

\begin{abstract}
The present study aims to evaluate the reality of the services provided to children with cerebral palsy from the guardians' perspective and its relation to some relevant variables (i.e. branch of the association, educational level of the parents, monthly income, and number of years for receiving the associations' services). The study was applied to the families of children with cerebral palsy in (10) centers of the Association of Disabled Children in Saudi Arabia. Therefore, a tool for data collection was prepared and verified for validity and reliability. It comprised (47) items distributed to (6) domains. The results showed that the arithmetic means of the domains ranged from $(0.65)$ to $(0.84)$. While "the performance of the administration and staff" was ranked first with an arithmetic mean of (0.84), "the supporting services" domain was ranked last with an arithmetic mean of (0.65), and the tool's arithmetic mean was (0.71). Additionally, there are no statistically significant differences for (the academic qualification of the father, academic qualification of the mother, average monthly income, and number of years for receiving the associations' services) variables. The study concluded that there is an urgent need to improve the services provided to children with cerebral palsy in all domains, especially in the Western Region of Saudi Arabia.
\end{abstract}

Keywords: Cerebral palsy, Families, Association of disabled children, Rehabilitation services

\section{Introduction}

Interest in cerebral palsy dates back to the nineteenth century when the surgeon Little (1843) described its symptoms in early detection. Thus, spastic diplegia was called "Little's disease", and surgery was the primary form of treatment. Freud paid attention to cerebral palsy when he was a neurologist. In the second half of the twentieth century, interest in children with cerebral palsy increased in America and Europe, and the American Academy for Cerebral Palsy and Developmental Medicine and a center and clinic for cerebral palsy in Sweden were established. Later, such interest extended by setting the centers and clinics for cerebral palsy in many areas including Eastern Europe and the developing countries, especially the Arab 
counties (Alsaratowy \& Alsamady, 2010).

Such developments and researches were reflected on the nature of the services provided to children with cerebral palsy. In other words, treatment shifted from surgery to educational rehabilitation. Neuromotor training methods became popular, e.g. Bobath concept and Doman-Delacato method. Furthermore, the available services were improved to the extent that many disciplines could collaborate to deliver them although they rely on the medical aspect. This modern approach resulted in the development of the rehabilitation and educational services and the preventive programs and services, the accuracy of diagnosis, and the early detection of the various types of cerebral palsy (Alsaratowy \& Alsamady, 2010).

\section{Cerebral Palsy}

It is one of the developmental or neurological disorders that affect the brain in the early childhood, especially when there is a lesion in the motor cortex. It results from a disorder or damage in the brain and causes an unlimited number of symptoms and motor, sensory, and neural problems in the form of spasm, clonus in the movement of posture, along with spasticity in a particular limb, palsy or lack of motor balance, mental disorders, epileptic seizures, dyslexia, speech disorders, or weakness in some sensory organs, e.g. hearing and vision. They affect the sensory, cognitive, and emotional developmental aspects. Additionally, muscles are weak and the child's ability to move and learn (Alrosan, 2015).

\section{Classification According to Disability}

Disability, in its various forms, is an inhomogeneous category, and there are clear individual differences according to the degree, cause, form, or severity. Therefore, cerebral palsy has various classifications, including motor functioning, topographical distribution, and severity level because children with disabilities differ in their mental and behavioral abilities, social maturity, or posture. They also differ in terms of the causes for disability; the ability to learn, train, social adjustment, and emotional control; communication means related to the receptive and expression languages. This classification helps the designers of the educational programs for the children with disabilities deeply understand and develop the appropriate programs for each category (Alrosan, 2015; Alazza, 2001). Classification based on severity level:

- Mild cerebral palsy occurs when a child may not need therapeutic intervention, can take care of himself/ herself, and can move without assistance.

- Moderate cerebral palsy occurs when a child moves slowly, controls the muscle movement and walks without help. Furthermore, he/ she lacks medical services to overcome the problems related to speech and self-care.

- Severe cerebral palsy occurs when a child's movement is severely disabled, and the ability to self- care and speech is limited. Thus, he/ she needs regular, continuous and intensive treatment (Alsaratowy \& Alsamady, 2010; Alazza, 2001; Abdulla, Hammoda, Almohammady, Alrashedy,\& Alnajjar, 2009; Ahmed, 2009).

To conclude, the child with mild and moderate cerebral palsy can perform the assigned tasks and has the ability to accomplish his/ her roles and meet his/ her needs naturally. Those with severe cerebral palsy have a poor ability to perform their roles and to satisfy their needs. They also need an extensive, organized, and continuous treatment (Alkhatib, 2003).

In evaluating the benefit of the educational services to the disabled, it should not be limited to 
the improvement of the person. Instead, it should cover the positive social, psychological, and economic effects on the family and community, in general (Alqarutey, Alsaratawy, \& Alsamady, 2015).

The present study investigates the reality of the services provided to children with cerebral palsy from the perspective of the families. It helps to identify the weaknesses in the nature of the services and programs and develop and improve them, as possible.

\section{Statement of the Problem}

Recently, the interest in the educational services and programs offered to the children with disabilities has increased due to the direct attention of the decision-makers, specialists, authors, and guardians. Many legislations and laws have been issued requiring communities to provide the appropriate educational, social, and health care to those people in order to meet the satisfaction of all those interested in educating and taking care of this category, including the guardians. They declared the participation with the service centers as a success factor in providing these services in addition to the importance of identifying the guardians' perspectives due to their significant role in investigating the reality of these services to help develop an action plan. Although the guardians are the most familiar with the needs of the students, many questions raised about their satisfaction with the services provided by the centers and institutions to their children. Thus, the author was motivated to conduct the present study which attempts to answer the following questions:

1) What is the reality of the services provided to children with cerebral palsy from the guardians' perspective?

2) Does the level of the guardians' satisfaction with the services provided to children with cerebral palsy differ according to the geographical region (branch)?

3) Do the families' perspectives of the reality of the provided services differ according to the educational level of the parents, average monthly income, and number of years for receiving the associations' services?

\subsection{Objectives}

The study aims to highlight the reality of services provided to children with cerebral palsy from the guardians' perspective based on some variables and to identify the differences in their satisfaction due to the interaction of these variables. It also aims to:

- Investigate the reality of services provided for children with cerebral palsy from the parents' perspective.

- Define the most important needs and services needed by the children with cerebral palsy.

- Help increase the information on the services provided to the children with cerebral palsy.

\subsection{Significance}

It is a significant study because its results exposed the reality of the services provided to the children with cerebral palsy from their families' perspective. This result shall help the specialists, authors, and decision-makers to work on improving the level of the services provided to the children in order to obtain more support for these programs and services, achieving satisfaction with them. Theoretically, the study is significant as it focuses on investigating the services provided by the Association of Disabled Children to help make the 
public policy related to the programs and services offered to the children with cerebral palsy and to develop such programs and services efficiently and effectively. It may help conduct further studies related to those with cerebral palsy in order to promote the level of services provided.

Practically, it is a modern study and affords data on the level of services provided to the children with cerebral palsy from the guardians' perspective, investigates the obstacles, and helps develop a strategy to improve the educational services and programs due to adopting many dimensions in terms of the services provided to children at the association. It benefits the decision-makers develop these programs to fulfill the education and training needs and services. It can help the officials prepare the remedial and educational programs and services, and the families get familiar with the educational programs and services offered to their children at the association in order to develop such programs. It designs a questionnaire that helps scrutinize the type of the services and programs provided to the children with cerebral palsy to keep up with the scientific and practical development and to investigate the status of the association to define the strengths, weaknesses, and need for the programs and services offered to develop them.

\subsection{Limitations}

\subsubsection{Objective Limitations}

Investigating the reality of the services provided to children with cerebral palsy from the guardians' perspective based on some variables and their interaction.

\subsubsection{Spatial Limitations}

The study was applied to the guardians of children enrolled at the (10) centers of the Association of Disabled Children in Saudi Arabia.

\subsubsection{Temporal Limitations:}

The second semester of $2017 / 2018$

\section{Definition of Terms}

\subsection{Cerebral palsy}

According to Alshakhs and Aldamaty (2000), WHO defines cerebral palsy as a case in which there is an abnormal shift in the movement or effectiveness due to failure, injury, or disease in the central nervous system. Procedurally, they are the children who attend the Association of Disabled Children and are diagnosed by specialized and certified centers as having cerebral palsy.

Rehabilitation services procedurally, they are the health care, educational, psychological, rehabilitation, professional, cultural, and media facilities, programs, materials, devices, and methods to the children with cerebral palsy enrolled at the Association of Disabled Children. They include the intervention and referral, assessment and diagnosis, individual educational plan, supporting services, performance of the administration and staff, and evaluation (outputs), as expressed by the measure adopted by the study from the guardians' perspective.

The guardians

The relatives of the child with disability who take care of him/ her at home. They are often the parents. 


\section{Macrothink}

\section{Conceptual Framework and Literature Review}

The services provided to the children with cerebral palsy essentially aim to develop and equip them with skills to increase their independence and to activate their participation to the various community activities (Alqarutey et al., 2013). This section highlights cerebral palsy through concept, historical overview of the efforts exerted in the definition and classification, models, philosophies and theories, comparison of the services, making a proposal, and issues, e.g. referral and diagnosis, and relevant literature.

Many international laws have been issued requiring learning and offering services to the children with disabilities. For example, the Education of All Handicaped ACT (EHA) in1975 claimed that special education and relevant services shall be available to the school student with disabilities. It was redrafted in the Individuals with Disabilities Education Act (IDEA) in 1990 declared that children with disabilities shall receive free education at schools. It covered developing special educational programs and supporting services that meet their needs and qualify them for an independent life as much as possible (Downing, 2004).

The Council for Exceptional Children (CEC) paid attention to the services and practices offered to the disabled children in terms of administration, instructors, advisors, and guardians (Robertson, 2006). The present study addresses the services to the children with disabilities from the guardian' perspective because of its importance in evaluating such direct services (Alsaree, 2014).

\subsection{Evaluation Criteria for Cerebral Palsy}

Evaluation involves collecting data on the child to make decisions about him/ her. It is made for two main reasons, as follows:

Diagnosis: The child should be diagnosed as disabled. Consequently, the decision of providing special education services is justified.

Planning of the educational programs:

The useful evaluation helps determine what and how the child shall learn.

\subsection{Early Detection of Cerebral Palsy}

\section{- Preliminary stage}

In this stage, the manifestations of cerebral palsy are recognized. It is better to detect cerebral palsy in the early months of age. However, it may be hard for some cases, until the age of a year or more. Cerebral palsy cannot be affirmed but after observing all the manifestations (Ahmed \& Mostafa, 2014).

\section{Diagnosis}

In order to make sure that the child has cerebral palsy, comprehensive diagnosis procedures shall be taken, where many physicians take part, including the neurologist, pediatrician, ophthalmologist, otorhinolaryngologist, psychologist, social worker, speech-language pathologist, and special education specialist.

The treatment is primarily based on the psychoeducational evaluation where the data on the student's performance are collected and discussed in order to arrange the needed support services and to make the adequate educational modifications (Association of Disabled Children, 2010). 
- Medical diagnosis:

- The accurate diagnosis is based on the results of the approved examination procedures including clinical examination, electroencephalography, computed tomography scan, x-rays, encephalo arteriography, as well as routine lab tests, e.g. blood and urine tests in order to identify any chemical disorders that may cause poisoning in relation to cerebral palsy.

Other tests and medical procedures to evaluate the physical status of the child or to detect the pre-birth genetic disorders are conducted. Additionally, the physician shall conduct a comprehensive study covering the medical history, family history, and any data that can help the physician understand the case and enhance the accuracy of diagnosis thoroughly (Ahmed, 2014).

Psychoeducational diagnosis:

According to Ahmed (2014), the aspects of cognitive and psychological development are evaluated to identify their strengths and weaknesses. It helps recognize problems and disabilities associated with cerebral palsy related to the cognitive and emotional aspects.

Therefore, many countries, including Saudi Arabia, have paid attention to the education of those with disabilities as citizens with rights to the adequate learning and rehabilitation, considering that the care for them and offering the educational and rehabilitation services human, social, and economic needs (Almousa, 2008).

To succeed, the programs and services of special education depend on a set of factors such as parental participation where the parents participate in the relevant activities and programs on or off school campus and their perspectives towards these services are surveyed and evaluated (Alhazemy, 2009).

Family is the primary unit of society. It is the link between the individual and society or the link between culture and personality. It is the first human medium where the student grows up and acquires the behavioral schemes that enable him/ her to satisfy the needs, achieve potentials, and adjust with the community (Kafafy, 2009).

Thus, family members, especially parents, play an important role in the educational and medical programs offered to the student as they are the closest to him/ her and give unparalleled love and tenderness (Wehman, 1998).

If taking care of the normal student difficult, it is more difficult for the disabled, where the family addresses problems and special challenges. According to Elkhatib (2008), disability is often associated with psychological, social, educational, and medical pressures for the guardians.

The educational environment of the children with disabilities requires making modifications and adjustments. It is not limited for a classroom and a teacher only, but the modifications vary according to the special needs. With the growing understanding of students with disabilities, the concept of learning environment developed and the social and philosophical trends of raising them to be productive and independent citizens evolved (Alwaqfey, 2008).

According to Aloteby (2007), Johnson and Duffett (2002) argued that family satisfaction is the most significant factor in evaluating the programs and services provided to those with special needs and their guardians. Additionally, the IDEA argued for involving the guardians, as decision-makers, in the teamwork assigned for their children. It may help mitigate their 
feelings of dissatisfaction with the services provided and gives them the opportunity to express their views about their perceptions on such programs.

Some studies reported that the guardians who are unsatisfied with their relationships with the school suffer from the feeling that they are not welcomed in the teamwork when applying the programs and services to their children.

Additionally, the participation of the parents in the educational activities help improve the relationship with the teacher, improve their understanding of special education, and increase the information about the academic achievement of the student, clarity of the program's objectives and instructions to them (Gallagher, 1995).

To conclude, investigating the reality of the services provided by the Association of Disabled Children to the children with cerebral palsy from the guardians' perspective helps to improve them. This can result in offering distinctive and various adequate services to the children and can improve the satisfaction of the guardians with such services, improving their psychosocial adjustment.

\section{Review of Literature}

UNICEF (2002) aimed to evaluate the centers and institutions that provide services to the people with disabilities. The study surveyed (40) families to investigate their perspectives on such services at the special education institutions in Jordan. The results revealed the impact of the centers on the educational, emotional, and financial and the dissatisfaction of the parents with the low supporting services for occupational therapy, speech therapy, and behavior modification.

Hamplin and Musa (2006) aimed to plan and implement a three-year project that offers rehabilitation services to the families of children with cerebral palsy. The study covered (22) children and revealed the significant improvement in the children and their families as the guardians acquired experiences of treating their children through care and continuous guidance by the teamwork. It reported the importance of familial care and rehabilitation to the children with disabilities.

Siebes et al. (2006) investigated parent participation in and satisfaction with the services offered to children with special needs. The study revealed that the parents participate in all stages of rehabilitating the children and their satisfaction was high.

Aloteby (2007) considered the satisfaction of the guardians with special needs with the provided services in the special education programs in Saudi Arabia. It applied a 35-item tool to (1224) families. The results revealed a general, but not, high satisfaction with the services provided to those with disabilities at the institutes and programs for the people with disabilities. There were no differences in satisfaction between the males and females, and there were no differences in satisfaction according to the age group. However, there were significant differences among the illiterates, literates, holders of primary certificate, and holders of university degree. The satisfaction of the guardians of the students with physical disabilities was rated first, followed by those with mental disabilities, visual impairment, hearing impairment, behavioral disorders, multiple disabilities, and autism.

Alghaliat (2008) evaluated the health and educational services offered to the children with cerebral palsy in Jordan. The study applied a tool of evaluating the educational and health 
services to (350) guardians from the health and educational centers for those with cerebral palsy at the different governorates. Results indicated that the health and educational services offered to the children with cerebral palsy were rated medium. Although there were differences according to the geographical region, there were no differences according to the sex of the child.

Livingstone (2008) examined the understanding, perception, and satisfaction of the guardians of children with disabilities with special education services in the elementary and pre-school services. The study also surveyed their perspectives with understanding and perceiving information on special education. It covered (230) guardians of elementary school students enrolled in special education programs in North Texas School. The questionnaire analysis covered three domains: 1. Evaluation of the psychometric properties, 2- examining the differences among the different types of fathers and mothers, and 3- urging parents to express opinions and feedback on the ways of improving the special education services.

The parents showed a great satisfaction with the special education services provided to the children. They expressed understanding and awareness of this process. In addition, there were differences among the parent groups where those with two or three children expressed greater satisfaction with the services than those with one child. Results reported the importance of training the parents on special education programs and enhancing communication with them in the trustee board meetings. Additionally, they reported utilizing such meetings with therapists and using e-mail as a source of information about special education.

Alfawaeer (2013) evaluated early intervention services of children with special needs in Oman from the family perspective. The study applied the family outcomes survey to (53) families. Results revealed that (78\%) of the families reported positive evaluation and $(22 \%)$ reported negative evaluation of the intervention programs. There were no statistically significant differences on the early intervention services according to the variables of guardians and sex of the children. there were statistically significant differences on the nature of the services. Additionally, the families were dissatisfied with the benefits of early intervention programs in identifying family rights and supporting the child with special needs.

Wang et al. (2014) evaluated the family-centered services from parents of Chinese children with cerebral palsy with the measure of processes of care. The study covered the parents of the children with cerebral palsy under the age of eight who received rehabilitation services between May 2012 and May 2013 and who also received rehabilitation services in outpatient clinics and centers in 2013. It illustrated the dissatisfaction of the guardians of children with cerebral palsy with the adequacy of services to their children. It suggested many actions to improve such services.

\section{Commentary}

Literature diversified in terms of the objectives, method, implementation, and procedures. The author reviewed some relevant Arab and foreign studies. Although these studies were conducted in different educational environment and systems, they were silmilar to that of the present study. By reviewing literature, the similarities and differences with the present study are defined, helping develop the study. 


\subsection{Similarities and Differences Between the Present Study and Literature}

Literature addressed the services provided to the children with different disabilities (autism, auditory, learning disabilities...etc.). However, no study covered the cerebral palsy, except for Wang et al. (2014) in China, revealing the dissatisfaction of guardians with the services provided to their children although some of them urgently need identifying and developing them.

Furthermore, the studies comprised different variables and samples. For example, Aloteby (2007) was applied to the Saudi community and Alfawaeer (2013) was applied to the Omani community. While Livingstone (2008) was applied to guardians in North Texas, Wang et al. (2014) was conducted in China and covered children with different disabilities including cerebral palsy.

The present study differs from literature in terms of the sample. It covered (192) guardians of children with cerebral palsy at the Association of Disabled Children. It applied a 47-item tool distributed to (6) domains, namely intervention and referral (10 items), diagnosis (10) items, preparation and implementation of the educational plan (9) items, supporting services (7) items, performance of the administration and staff (6) items, and evaluation (outputs) (5) items. They were developed to suit the reality of the Association of Disabled Children, as well as satisfaction of the guardians with the nature of the rehabilitation, educational, and supporting services. Thus, the present study highlights the reality of these services from the guardians' perspective.

The study also differs in terms of the measurement tools. For example, Wang et al. (2014) applied a 20 -item tool to evaluate the availability of rehabilitation services to the guardians of children with cerebral palsy. Alfawaeer (2013) applied family outcomes survey to (53) families, Livingstone (2008) applied a questionnaire that covered three domains, i.e. evaluation of the psychometric properties, examining the differences among the different types of fathers and mothers, and urging parents to express opinions and feedback on the ways of improving the special education services. Aloteby (2007) adopted a 35-item tool to measure family satisfaction.

The present study adds to literature evaluating the reality of the services offered to children with cerebral palsy at the Association of Disabled Children from the guardians' perspective. It develops a new tool (prepared by the author) to be used in other studies, as well as discussing the present results.

\section{Procedures}

The following procedures were conducted: After defining the population and sampling, a tool was developed. Then, the reliability coefficients were estimated by applying the tool to a pilot sample of (30) guardians of children at the Association of Disabled Children. Later, a formal correspondence was sent to the administration of the association to facilitate the author's mission by applying the tool of the study. The questionnaire was applied to all the participants with explaining its objectives and purpose to the heads of departments who distributed the tool to the guardians' groups via a google drive link. It was highlighted that the tool is designed for scientific research purposes only. After obtaining the responses, they were extracted and analyzed using SPSS. Then, the results were analyzed and discussed, and 


\section{Macrothink}

the recommendations were made.

\subsection{Method}

The study adopted the descriptive approach and the statistical method to analyze the field results. It utilized the frequencies, arithmetic means, and percentages for data collection and variance analysis for identifying the statistical significances of the differences among the participants.

\section{Population and Sampling}

The study covered the guardians of children with disabilities at the Association of Disabled Children in the second semester of 2017/2018. The sample comprised (192) guardians of children aged (4-12) years with (multiple) disability who benefit from the educational programs at the center. The participants' mental disability shall be simple only to benefit from these programs. Additionally, the visual and auditory senses shall enablle him/ her benefit from these programs (Documents of the Association, 2018). The sample comprised those who agreed to participate, as shown in table (1).

Table 1. Distribution of the participants according to the study variables

\begin{tabular}{|c|c|c|c|}
\hline Variable & Categories & Frequency & Percentage \\
\hline \multirow{2}{*}{$\begin{array}{l}\text { Academic qualification } \\
\text { of the father }\end{array}$} & Less than secondary & 23 & 12.0 \\
\hline & Secondary and more & 169 & 88.0 \\
\hline \multirow{2}{*}{$\begin{array}{l}\text { Academic qualification } \\
\text { of the mother }\end{array}$} & Less than secondary & 31 & 16.1 \\
\hline & Secondary and more & 161 & 83.9 \\
\hline \multirow{2}{*}{$\begin{array}{l}\text { Average } \\
\text { income }\end{array}$} & SR 9, 000 and less & 109 & 56.8 \\
\hline & SR 9, 000 and more & 83 & 43.2 \\
\hline \multirow{2}{*}{$\begin{array}{l}\text { Branch } \\
\text { association }\end{array}$} & Central region & 33 & 17.2 \\
\hline & Western region & 109 & 56.8 \\
\hline \multirow{7}{*}{$\begin{array}{l}\text { Number of years fo } \\
\text { receiving th } \\
\text { associations' services }\end{array}$} & Northern region & 23 & 12.0 \\
\hline & Southern region & 27 & 14.1 \\
\hline & One & 41 & 21.4 \\
\hline & Two & 40 & 20.8 \\
\hline & Three & 49 & 25.5 \\
\hline & Four and more & 62 & 32.3 \\
\hline & Total & 192 & 100.0 \\
\hline
\end{tabular}

\section{Tool}

To achieve the objective of the study, i.e. evaluation of the services provided to children with cerebral palsy from the guardians' perspective, the author developed a tool after reviewing the relevant literature. He utilized the scales of Alayed (2012), Aloteby (2007), Alnajjar 
(2014), and the national study to describe autism services. Consequently, the tool consisted of two parts. While the first part comprises demographic information about the variables (i.e. sex, age, educational level, number of disabled children, and disability category), the second one covered (the reality of the services provided to the children with cerebral palsy from the guardians' perspective). After that, the items were created and formulated considering academic and language accuracy, freedom of ambiguity, content representation, appropriateness to the guardians, and clarity of instructions.

- The preliminary form of the test: The tool consisted of (47) items distributed to (6) domains, namely intervention and referral (10 items), diagnosis (10) items, preparation and implementation of the educational plan (9) items, supporting services (7) items, performance of the administration and staff (6) items, and evaluation (outputs) (5) items. The participants should choose agree or disagree.

\section{Validity and Reliability}

\subsection{Content Validity}

After drafting the items, the tool was submitted to a group of reviewers specialized in special education at Imam Muhammad Ibn Saud Islamic University to explore their views on the appropriateness of the domains and items, proper academic and language formulation, and adequacy of the items.

Based on the notes of the reviewers, some modifications were inserted. In its final form, the tool comprised (47) items distributed to the following domains: intervention and referral, diagnosis, preparation and implementation of the educational plan, supporting services, performance of the administration and staff, and evaluation (outputs).

\subsection{Construct Validity}

To get the significance of the construct validity, the correlation coefficients of the items with the total score were estimated in a pilot sample of (40) guardians. The items were analyzed, and the correlation coefficient of each items was calculated. The validity of the item is defined by its correlation coefficient to the total score, to the domain, and between the domain and the total score. The correlation coefficients of the items and the tool ranged from $(0.40)$ to $(0.85)$ and to the domain from $(0.46)$ to $(0.91)$ (Table 2).

Table 2. Correlation coefficients of the item to the total score and domain

\begin{tabular}{|c|c|c|c|c|c|c|c|c|}
\hline No. & $\begin{array}{l}\text { Correlation } \\
\text { coefficient of the } \\
\text { Domain }\end{array}$ & $\begin{array}{l}\text { Correlation } \\
\text { coefficient } \\
\text { to the tool }\end{array}$ & No. & $\begin{array}{l}\text { Correlation } \\
\text { coefficient } \\
\text { of the } \\
\text { Domain }\end{array}$ & $\begin{array}{l}\text { Correlation } \\
\text { coefficient } \\
\text { To the tool }\end{array}$ & No. & $\begin{array}{l}\text { Correlation } \\
\text { coefficient } \\
\text { of the } \\
\text { Domain }\end{array}$ & $\begin{array}{l}\text { Correlation } \\
\text { coefficient } \\
\text { To the tool }\end{array}$ \\
\hline 1 & $.67 * *$ & $.40 *$ & 17 & $.73^{* *}$ & $.56^{* *}$ & 33 & $.74 * *$ & $.68^{* *}$ \\
\hline 2 & $.49^{* *}$ & $.45^{* *}$ & 18 & $.82 * *$ & $.65^{* *}$ & 34 & $.73^{* *}$ & $.60^{* *}$ \\
\hline 3 & $.56^{* *}$ & $.52 * *$ & 19 & $.78^{* *}$ & $.65^{* *}$ & 35 & $.80 * *$ & $.70^{* *}$ \\
\hline 4 & $.53 * *$ & $.42 * *$ & 20 & $.46^{* *}$ & $.55^{* *}$ & 36 & $.73^{* *}$ & $.52 * *$ \\
\hline 5 & $.56^{* *}$ & $.42 * *$ & 21 & $.79 * *$ & $.61^{* *}$ & 37 & $.75^{* *}$ & $.63^{* *}$ \\
\hline
\end{tabular}




\section{Macrothink}

International Research in Education

ISSN 2327-5499

2019, Vol. 7, No. 1

\begin{tabular}{|c|c|c|c|c|c|c|c|c|}
\hline No. & $\begin{array}{l}\text { Correlation } \\
\text { coefficient of the } \\
\text { Domain }\end{array}$ & $\begin{array}{l}\text { Correlation } \\
\text { coefficient } \\
\text { to the tool }\end{array}$ & No. & $\begin{array}{l}\text { Correlation } \\
\text { coefficient } \\
\text { of the } \\
\text { Domain }\end{array}$ & $\begin{array}{l}\text { Correlation } \\
\text { coefficient } \\
\text { To the tool }\end{array}$ & No. & $\begin{array}{l}\text { Correlation } \\
\text { coefficient } \\
\text { of the } \\
\text { Domain }\end{array}$ & $\begin{array}{l}\text { Correlation } \\
\text { coefficient } \\
\text { To the tool }\end{array}$ \\
\hline 6 & $.74 * *$ & $.72 * *$ & 22 & $.71 * *$ & $.57 * *$ & 38 & $.80 * *$ & $.56^{* *}$ \\
\hline 7 & $.64 * *$ & $.67^{* *}$ & 23 & $.64 * *$ & $.52 * *$ & 39 & $.80 * *$ & $.57 * *$ \\
\hline 8 & $.67 * *$ & $.45^{* *}$ & 24 & $.71 * *$ & $.63 * *$ & 40 & $.71 * *$ & $.56^{* *}$ \\
\hline 9 & $.62 * *$ & $.54 * *$ & 25 & $.82 * *$ & $.74 * *$ & 41 & $.88 * *$ & $.56^{* *}$ \\
\hline 10 & $.70 * *$ & $.67^{* *}$ & 26 & $.91 * *$ & $.72 * *$ & 42 & $.76^{* *}$ & $.62 * *$ \\
\hline 11 & $.84 * *$ & $.77 * *$ & 27 & $.72 * *$ & $.63 * *$ & 43 & $.82 * *$ & $.73 * *$ \\
\hline 12 & $.83 * *$ & $.85^{* *}$ & 28 & $.47 * *$ & $.40 *$ & 44 & $.77 * *$ & $.60 * *$ \\
\hline 13 & $.84 * *$ & $.72 * *$ & 29 & $.76^{* *}$ & $.58 * *$ & 45 & $.81^{* *}$ & $.66^{* *}$ \\
\hline 14 & $.89 * *$ & $.71 * *$ & 30 & $.87 * *$ & $.66^{* *}$ & 46 & $.83 * *$ & $.70 * *$ \\
\hline 15 & $.86^{* *}$ & $.71 * *$ & 31 & $.65^{* *}$ & $.52 * *$ & 47 & $.75^{* *}$ & $.65^{* *}$ \\
\hline 16 & $.79 * *$ & $.59 * *$ & 32 & $.85 * *$ & $.75 * *$ & & & \\
\hline
\end{tabular}

* Statistically significant at the level of (0.05)

** Statistically significant at the level of (0.01)

It is noted that all correlation coefficients were positive, statistically significant, and rated (medium to high), suggesting the construct validity. Thus, no items were deleted.

Table 3. Correlation coefficients between the domains and the total score

\begin{tabular}{|c|c|c|c|c|c|c|c|}
\hline & $\begin{array}{l}\text { Intervention } \\
\text { and referral }\end{array}$ & Diagnosis & $\begin{array}{l}\text { Preparation and } \\
\text { implementation of } \\
\text { the educational plan }\end{array}$ & $\begin{array}{l}\text { Supporting } \\
\text { services }\end{array}$ & $\begin{array}{l}\text { Performance of } \\
\text { the administration } \\
\text { and staff }\end{array}$ & $\begin{array}{l}\text { Evaluation } \\
\text { (outputs) }\end{array}$ & $\begin{array}{l}\text { Total } \\
\text { score }\end{array}$ \\
\hline $\begin{array}{l}\text { Intervention and } \\
\text { referral }\end{array}$ & 1 & & & & & & \\
\hline Diagnosis & $.688 * *$ & 1 & & & & & \\
\hline $\begin{array}{l}\text { Preparation and } \\
\text { implementation of } \\
\text { the educational plan }\end{array}$ & $.525^{* *}$ & $.503 * *$ & 1 & & & & \\
\hline Supporting services & $.535^{* *}$ & $.596^{* *}$ & $.602 * *$ & 1 & & & \\
\hline $\begin{array}{l}\text { Performance of the } \\
\text { administration and } \\
\text { staff }\end{array}$ & $.401 * *$ & $.753 * *$ & $.445^{* *}$ & $.583 * *$ & 1 & & \\
\hline Evaluation (outputs) & $.501^{* *}$ & $.592 * *$ & $.782 * *$ & $.720 * *$ & $.552 * *$ & 1 & \\
\hline
\end{tabular}




$\begin{array}{llllllll}\text { Total score } & .770 * * & .865 * * & .800 * * & .823 * * & .748 * * & .840 * *\end{array}$

* Statistically significant at the level of (0.05)

** Statistically significant at the level of $(0.01)$

All correlation coefficients were positive and statistically significant, suggiesting the construct validity.

\section{Reliability}

Reliability is the consistency of a measure. The measure is reliable if the participant obtained the same or close degree in the test or a set of equal or parallel questions when applied more than once (Abuallam, 2010).

To test the reliability of the tool, it was verified using test-retest approach by applying the questionnaire and reapplying it after two weeks to a group, not from the sample comprising (40) participants. Pearson Correlation Coefficient was calculated in the two times.

Additionally, the reliability coefficient was calculated based on internal consistency using Cronbach's alpha. Table (4) shows the internal consistency based on Cronbach's Alpha and test-retest reliability of the domains and the total score. The values were found adequate to the purposes of the study.

Table 4. Cronbach's Alpha and test-retest reliability of the domains and the total score

\begin{tabular}{lll}
\hline Domain & Test-Retest Reliability & Content validity \\
\hline Intervention and referral & 0.92 & $\mathbf{0 . 8 1}$ \\
Diagnosis & 0.94 & $\mathbf{0 . 9 2}$ \\
Preparation and implementation of the educational plan & 0.90 & $\mathbf{0 . 8 9}$ \\
Supporting services & 0.91 & $\mathbf{0 . 8 8}$ \\
Performance of the administration and staff & 0.92 & $\mathbf{0 . 8 6}$ \\
Evaluation (outputs) & 0.89 & $\mathbf{0 . 8 5}$ \\
Total score & 0.94 & $\mathbf{0 . 9 5}$ \\
\hline
\end{tabular}

\section{Results and Discussion}

The first question: What is the reality of the services provided to children with cerebral palsy from the guardians' perspective?

To answer this question, the arithmetic means and standard deviations of each domain and the tool were estimated, as shown in Table 5. 
Table 5. Arithmetic means and standard deviations of each domain and the tool in a descending order

\begin{tabular}{lllll}
\hline Rank & No. & Domain & Arithmetic mean & Standard deviation \\
\hline 1 & 5 & Performance of the administration and staff & 0.84 & 0.270 \\
2 & 2 & Diagnosis & 0.72 & 0.325 \\
3 & 1 & Intervention and referral & 0.69 & 0.241 \\
4 & 3 & $\begin{array}{l}\text { Preparation and implementation of the } \\
\text { educational plan }\end{array}$ & 0.69 & 0.324 \\
5 & 6 & Evaluation (outputs) & 0.69 & 0.350 \\
6 & 4 & Supporting services & 0.65 & 0.334 \\
& & Total score & 0.71 & 0.244 \\
\hline
\end{tabular}

Table 5 shows that the arithmetic means of the domains ranged from (0.65) to (0.84). While "the performance of the administration and staff" was ranked first with an arithmetic mean of (0.84), "the supporting services" domain was ranked last with an arithmetic mean of (0.65), and the tool's arithmetic mean was (0.71). As a result, the reality of services provided to the children with cerebral palsy from the guardians' perspective was rated medium. This result matches the result of Aloteby (2007) and Alghaliat (2008) in Jordan. It differs from the results of Wang et al. (2014).

Frequencies and percentages of the participants' responses to each domain were calculated, as follows:

I. Intervention and referral

Table 6. Frequencies and percentages of the items of "intervention and referral" in a descending order

\begin{tabular}{|c|c|c|c|c|c|c|}
\hline \multirow{2}{*}{ Rank } & \multirow{2}{*}{ No. } & \multirow{2}{*}{ Items } & \multicolumn{2}{|l|}{ Agree } & \multicolumn{2}{|l|}{ Disagree } \\
\hline & & & Frequency & Percentage & Frequency & Percentage \\
\hline 1 & 3 & $\begin{array}{l}\text { I collaborate with specialists in providing the } \\
\text { necessary information about the child. }\end{array}$ & 185 & 96.4 & 7 & 3.6 \\
\hline 2 & 5 & $\begin{array}{l}\text { I participate with the specialists in taking the } \\
\text { decision of referring my child. }\end{array}$ & 171 & 89.1 & 21 & 10.9 \\
\hline 3 & 6 & $\begin{array}{l}\text { The referral procedures of my child were } \\
\text { suitable. }\end{array}$ & 150 & 78.1 & 42 & 21.9 \\
\hline 4 & 4 & $\begin{array}{l}\text { I receive a written notice of any measures } \\
\text { suggested or denied by the competent authorities } \\
\text { in the evaluation of my child. }\end{array}$ & 147 & 76.6 & 45 & 23.4 \\
\hline 5 & 2 & I gave a written consent on the referral of my & 146 & 76.0 & 46 & 24.0 \\
\hline
\end{tabular}




\begin{tabular}{|c|c|c|c|c|c|c|}
\hline \multirow{2}{*}{ Rank } & \multirow{2}{*}{ No. } & \multirow{2}{*}{ Items } & \multicolumn{2}{|l|}{ Agree } & \multicolumn{2}{|l|}{ Disagree } \\
\hline & & & Frequency & Percentage & Frequency & Percentage \\
\hline & & $\begin{array}{l}\text { child to the competent authorities to conduct } \\
\text { evaluation. }\end{array}$ & & & & \\
\hline 6 & 1 & $\begin{array}{l}\text { I have information on the referral of my child to } \\
\text { the competent authorities. }\end{array}$ & 133 & 69.3 & 59 & 30.7 \\
\hline 7 & 7 & The referral measures of my child were timely. & 132 & 68.8 & 60 & 31.3 \\
\hline 8 & 8 & $\begin{array}{l}\text { The referral was made to a body that offers } \\
\text { financial fund. }\end{array}$ & 96 & 50.0 & 96 & 50.0 \\
\hline 9 & 9 & $\begin{array}{l}\text { I got a list of centers that provide services for } \\
\text { people with disabilities. }\end{array}$ & 86 & 44.8 & 106 & 55.2 \\
\hline 10 & 10 & $\begin{array}{l}\text { I got publications (or books) with information on } \\
\text { the status of my child. }\end{array}$ & 80 & 41.7 & 112 & 58.3 \\
\hline
\end{tabular}

Table 6 shows that item (3), i.e. I collaborate with specialists in providing the necessary information about the child., was ranked first with a frequency of (185) and a percentage of (96.4), while item (10), i.e. I got publications (or books) with information on the status of my child., was ranked last with a frequency of (80) and a percentage of (41.7).

\section{Diagnosis}

Table 7. Frequencies and percentages of the items of "diagnosis" in a descending order

\begin{tabular}{|c|c|c|c|c|c|c|}
\hline \multirow{2}{*}{ Rank } & \multirow{2}{*}{ No. } & \multirow{2}{*}{ Items } & \multicolumn{2}{|l|}{ Agree } & \multicolumn{2}{|l|}{ Disagree } \\
\hline & & & Frequency & Percentage & Frequency & Percentage \\
\hline 1 & 14 & $\begin{array}{l}\text { I am satisfied with the way specialists handle the } \\
\text { diagnosis process. }\end{array}$ & 150 & 78.1 & 42 & 21.9 \\
\hline 2 & 15 & $\begin{array}{l}\text { I am satisfied with the diagnosis process in } \\
\text { general. }\end{array}$ & 145 & 75.5 & 47 & 24.5 \\
\hline 3 & 11 & $\begin{array}{l}\text { I got a report showing the performance of my } \\
\text { child, including strengths and weaknesses. }\end{array}$ & 141 & 73.4 & 51 & 26.6 \\
\hline 4 & 20 & $\begin{array}{l}\text { I participate the specialists in reviewing the } \\
\text { evaluation results of my child at the completion } \\
\text { of the evaluation process. }\end{array}$ & 141 & 73.4 & 51 & 26.6 \\
\hline 5 & 17 & I participated in the evaluation of my child. & 137 & 71.4 & 55 & 26.6 \\
\hline 6 & 16 & $\begin{array}{l}\text { The diagnosis tools applied to my child were } \\
\text { accurate and appropriate. }\end{array}$ & 136 & 70.8 & 56 & 29.2 \\
\hline 6 & 18 & $\begin{array}{l}\text { My contribution in the evaluation was a major } \\
\text { focus in evaluation. }\end{array}$ & 136 & 70.8 & 56 & 29.2 \\
\hline
\end{tabular}




\begin{tabular}{|c|c|c|c|c|c|c|}
\hline \multirow{2}{*}{ Rank } & \multirow{2}{*}{ No. } & \multirow{2}{*}{ Items } & \multicolumn{2}{|l|}{ Agree } & \multicolumn{2}{|l|}{ Disagree } \\
\hline & & & Frequency & Percentage & Frequency & Percentage \\
\hline 8 & 13 & $\begin{array}{l}\text { I am satisfied with the information provided } \\
\text { during diagnosis. }\end{array}$ & 135 & 70.3 & 57 & 29.7 \\
\hline 9 & 19 & The results of diagnosis were satisfactory. & 129 & 67.2 & 63 & 32.8 \\
\hline 10 & 12 & $\begin{array}{l}\text { I got a report including the recommended } \\
\text { services for my child. }\end{array}$ & 125 & 65.1 & 67 & 34.9 \\
\hline
\end{tabular}

Table 7 shows that item (14), i.e. I am satisfied with they way specialists handle the diagnosis process., was ranked first with a frequency of (150) and a percentage of (78.1), while item (12), i.e. I got a report including the recommended services for my child., was ranked last with a frequency of (125) and a percentage of (65.1).

III. Preparation and implementation of the educational plan

Table 8. Frequencies and percentages of the items of "preparation and implementation of the educational plan" in a descending order

\begin{tabular}{|c|c|c|c|c|c|c|}
\hline \multirow{2}{*}{ Rank } & \multirow{2}{*}{ No. } & \multirow{2}{*}{ Items } & \multicolumn{2}{|l|}{ Agree } & \multicolumn{2}{|l|}{ Disagree } \\
\hline & & & Frequency & Percentage & Frequency & Percentage \\
\hline 1 & 28 & $\begin{array}{l}\text { I help and train my child at home on the required } \\
\text { skills. }\end{array}$ & 167 & 87.0 & 25 & 13.0 \\
\hline 2 & 24 & $\begin{array}{l}\text { The teacher instructed me to follow up achieving } \\
\text { the set objectives at home. }\end{array}$ & 146 & 76.0 & 46 & 24.0 \\
\hline 3 & 29 & $\begin{array}{l}\text { The educational plan was related to the results of } \\
\text { evaluation. }\end{array}$ & 139 & 72.4 & 53 & 27.6 \\
\hline 4 & 27 & $\begin{array}{l}\text { I contact and give information to the specialists } \\
\text { on the progress my child at home. }\end{array}$ & 137 & 71.4 & 55 & 28.6 \\
\hline 5 & 23 & $\begin{array}{l}\text { I continually follow up the achievement of the } \\
\text { educational plan's objectives. }\end{array}$ & 136 & 70.8 & 56 & 29.2 \\
\hline 6 & 26 & $\begin{array}{l}\text { I am satisfied with the educational program for } \\
\text { my child. }\end{array}$ & 132 & 68.8 & 60 & 31.3 \\
\hline 7 & 22 & $\begin{array}{l}\text { The educational plan was related to the } \\
\text { curriculum. }\end{array}$ & 125 & 65.1 & 67 & 34.9 \\
\hline 8 & 25 & I am a member of the individual plan team. & 106 & 55.2 & 86 & 44.8 \\
\hline 9 & 21 & $\begin{array}{l}\text { I participated in the preparation of the } \\
\text { educational plan for my child. }\end{array}$ & 103 & 53.6 & 89 & 46.4 \\
\hline
\end{tabular}

Table 8 shows that item (28), i.e. I help and train my child at home on the required skills., was ranked first with a frequency of (167) and a percentage of (87.0), while item (21), i.e. I 
participated in the preparation of the educational plan for my child., wasi ranked last with a frequency of (103) and a percentage of (53.6).

IV. Supporting services

Table 9. Frequencies and percentages of the items of "supporting services" in a descending order

\begin{tabular}{|c|c|c|c|c|c|c|}
\hline \multirow{2}{*}{ Rank } & \multirow{2}{*}{ No. } & \multirow{2}{*}{ Items } & \multicolumn{2}{|l|}{ Agree } & \multicolumn{2}{|l|}{ Disagree } \\
\hline & & & Frequency & Percentage & Frequency & Percentage \\
\hline 1 & 30 & $\begin{array}{l}\text { The association has a unit for supporting } \\
\text { services offered by specialists. }\end{array}$ & 139 & 72.4 & 53 & 27.6 \\
\hline 2 & 35 & $\begin{array}{l}\text { The activities of the supporting services include } \\
\text { following- up the children in terms of health, } \\
\text { education, and rehabilitation. }\end{array}$ & 138 & 71.9 & 54 & 28.1 \\
\hline 3 & 33 & $\begin{array}{l}\text { The association evaluates the children's needs for } \\
\text { the supporting services. }\end{array}$ & 130 & 67.7 & 62 & 32.3 \\
\hline 4 & 32 & $\begin{array}{l}\text { A special plan of the supporting services for each } \\
\text { child is developed. }\end{array}$ & 127 & 66.1 & 65 & 33.9 \\
\hline 4 & 34 & $\begin{array}{l}\text { The families participate in providing the } \\
\text { supporting services to the children. }\end{array}$ & 127 & 66.1 & 65 & 33.9 \\
\hline 6 & 36 & $\begin{array}{l}\text { The association holding training courses for the } \\
\text { families to train them on dealing with the } \\
\text { children. }\end{array}$ & 119 & 62.0 & 73 & 38.0 \\
\hline 7 & 31 & $\begin{array}{l}\text { The number of specialists to the supporting } \\
\text { services is adequate to the number of children. }\end{array}$ & 98 & 51.0 & 94 & 49.0 \\
\hline
\end{tabular}

Table 9 shows that item (30), i.e. the association has a unit for supporting services offered by specialists., was ranked first with a frequency of (139) and a percentage of (72.4), while item (31), i.e. the number of specialists to the supporting services is adequate to the number of children., was ranked last with a frequency of (98) and a percentage of (51.0). This result does not match the result of UNICEF (2002).

V. Performance of the administration and staff

Table 10. Frequencies and percentages of the items of "performance of the administration and staff" in a descending order

\begin{tabular}{llllll}
\hline Rank & No. Items & Agree & & Disagree \\
& & Frequency & Percentage & Frequency & Percentage \\
\hline 1 & 39 & $\begin{array}{l}\text { The staff of the services are qualified and } \\
\text { specialized. }\end{array}$ & 166 & 86.5 & 26 \\
\hline
\end{tabular}




\begin{tabular}{|c|c|c|c|c|c|c|}
\hline \multirow{2}{*}{ Rank } & \multirow{2}{*}{ No. } & \multirow{2}{*}{ Items } & \multicolumn{2}{|l|}{ Agree } & \multicolumn{2}{|l|}{ Disagree } \\
\hline & & & Frequency & Percentage & Frequency & Percentage \\
\hline 2 & 38 & $\begin{array}{l}\text { The staff of the child services cooperate with } \\
\text { me. }\end{array}$ & 165 & 85.9 & 27 & 14.1 \\
\hline 3 & 37 & $\begin{array}{l}\text { I am satisfied with the performance of the } \\
\text { teacher(s) working with my child. }\end{array}$ & 163 & 84.9 & 29 & 15.1 \\
\hline 4 & 41 & $\begin{array}{l}\text { The staff are interested in offering services to } \\
\text { those with cerebral palsy relevant to the health, } \\
\text { rehabilitation, and education aspects. }\end{array}$ & 158 & 82.3 & 34 & 17.7 \\
\hline 5 & 40 & $\begin{array}{l}\text { The staff understand the nature and requirements } \\
\text { of cerebral palsy. }\end{array}$ & 157 & 81.8 & 35 & 18.2 \\
\hline 6 & 42 & $\begin{array}{l}\text { The staff of services for those with cerebral } \\
\text { palsy give many facilitations to obtain } \\
\text { information. }\end{array}$ & 158 & 79.7 & 39 & 20.3 \\
\hline
\end{tabular}

Table 10 shows that item (39), i.e. the staff of the services are qualified and specialized., was ranked first with a frequency of (166) and a percentage of (86.5), while item (42), i.e. the staff of services for those with cerebral palsy give many facilitations to obtain information., was ranked last with a frequency of (153) and a percentage of (79.7).

VI. Evaluation (outputs)

Table 11. Frequencies and percentages of the items of "evaluation (outputs)" in a descending order

\begin{tabular}{|c|c|c|c|c|c|c|}
\hline \multirow{2}{*}{ Rank } & \multirow{2}{*}{ No. } & \multirow{2}{*}{ Items } & \multicolumn{2}{|l|}{ Agree } & \multicolumn{2}{|l|}{ Disagree } \\
\hline & & & Frequency & Percentage & Frequency & Percentage \\
\hline 1 & 43 & $\begin{array}{l}\text { I am satisfied with achieving the annual and } \\
\text { short-term objectives in the individual plan for } \\
\text { the family and the child. }\end{array}$ & 144 & 75.0 & 48 & 25.0 \\
\hline 2 & 47 & $\begin{array}{l}\text { I review the periodic reports on the progress of } \\
\text { my child. }\end{array}$ & 143 & 74.5 & 49 & 25.5 \\
\hline 3 & 44 & $\begin{array}{l}\text { I got a notification with a prior consent to } \\
\text { re-evaluate my child. }\end{array}$ & 133 & 69.3 & 59 & 30.7 \\
\hline 4 & 45 & $\begin{array}{l}\text { I participate in the evaluation of the services } \\
\text { provided to my child. }\end{array}$ & 126 & 65.6 & 66 & 34.4 \\
\hline 5 & 46 & $\begin{array}{l}\text { I take part in setting the measurable annual and } \\
\text { short-term objectives to meet my child's needs. }\end{array}$ & 116 & 60.4 & 76 & 39.6 \\
\hline
\end{tabular}




\section{Macrothink}

Table 11 shows that item (43), i.e. I am satisfied with achieving the annual and short-term objectives in the individual plan for the family and the child., was ranked first with a frequency of (144) and a percentage of (75.0), while item (46), i.e. I take part in setting the measurable annual and short-term objectives to meet my child's needs., was ranked last with a frequency of (116) and a percentage of (60.4).

The second question: Does the level of the guardians'satisfaction with the services provided to children with cerebral palsy differ according to the geographical region (branch)?

To answer this question, the arithmetic means and standard deviations of the services provided to the children with cerebral palsy from the guardians' perspective were estimated according to the geographical region (branch), as shown in Table 12.

Table 12. Arithmetic means and standard deviations of the services provided to the children with cerebral palsy from the guardians' perspective according to the geographical region (branch)

\begin{tabular}{|c|c|c|c|c|}
\hline & Categories & Number & Arithmetic means & Standard deviation \\
\hline \multirow[t]{5}{*}{ Intervention and referral } & Central region & 33 & .75 & .231 \\
\hline & Western region & 109 & .67 & .239 \\
\hline & Northern region & 23 & .69 & .275 \\
\hline & Southern region & 27 & .71 & .228 \\
\hline & Total & 192 & .69 & .241 \\
\hline \multirow[t]{5}{*}{ Diagnosis } & Central region & 33 & .82 & .271 \\
\hline & Western region & 109 & .69 & .344 \\
\hline & Northern region & 23 & .68 & .355 \\
\hline & Southern region & 27 & .74 & .261 \\
\hline & Total & 192 & .72 & .325 \\
\hline \multirow{5}{*}{$\begin{array}{l}\text { Preparation and } \\
\text { implementation of the } \\
\text { educational plan }\end{array}$} & Central region & 33 & .79 & .275 \\
\hline & Western region & 109 & .61 & .347 \\
\hline & Northern region & 23 & .72 & .280 \\
\hline & Southern region & 27 & .85 & .220 \\
\hline & Total & 192 & .69 & .324 \\
\hline \multirow[t]{5}{*}{ Supporting services } & Central region & 33 & .76 & .280 \\
\hline & Western region & 109 & .62 & .347 \\
\hline & Northern region & 23 & .63 & .352 \\
\hline & Southern region & 27 & .68 & .315 \\
\hline & Total & 192 & .65 & .334 \\
\hline
\end{tabular}




\begin{tabular}{|c|c|c|c|c|}
\hline \multirow{5}{*}{$\begin{array}{l}\text { Performance of the } \\
\text { administration and staff }\end{array}$} & Central region & 33 & .97 & .074 \\
\hline & Western region & 109 & .79 & .299 \\
\hline & Northern region & 23 & .84 & .286 \\
\hline & Southern region & 27 & .85 & .231 \\
\hline & Total & 192 & .84 & .270 \\
\hline \multirow[t]{5}{*}{ Evaluation (outputs) } & Central region & 33 & .79 & .296 \\
\hline & Western region & 109 & .64 & .378 \\
\hline & Northern region & 23 & .58 & .295 \\
\hline & Southern region & 27 & .84 & .256 \\
\hline & Total & 192 & .69 & .350 \\
\hline \multirow[t]{5}{*}{ Total score } & Central region & 33 & .81 & .193 \\
\hline & Western region & 109 & .67 & .258 \\
\hline & Northern region & 23 & .69 & .265 \\
\hline & Southern region & 27 & .77 & .173 \\
\hline & Total & 192 & .71 & .244 \\
\hline
\end{tabular}

Table 12 shows apparent contradiction in the arithmetic means and standard deviations of the services provided to the children with cerebral palsy from the guardians' perspective based on the geographical region (branch). To illustrate the significance of the statistical differences of the arithmetic means, ANOVA was applied (Table 13).

Table 13. ANOVA of the impact of the geographical region (branch) on the services provided to the children with cerebral palsy from the guardians' perspective

\begin{tabular}{|c|c|c|c|c|c|c|}
\hline & Source & $\begin{array}{l}\text { Sum of } \\
\text { squares }\end{array}$ & $\begin{array}{l}\text { Freedom } \\
\text { degree }\end{array}$ & $\begin{array}{l}\text { Mean } \\
\text { squares }\end{array}$ & F value & $\begin{array}{l}\text { Statistical } \\
\text { significance }\end{array}$ \\
\hline \multirow{3}{*}{$\begin{array}{l}\text { Intervention } \\
\text { referral }\end{array}$} & Between groups & .199 & 3 & .066 & 1.148 & .331 \\
\hline & Within groups & 10.884 & 188 & .058 & & \\
\hline & Total & 11.083 & 191 & & & \\
\hline \multirow[t]{3}{*}{ Diagnosis } & Between groups & .522 & 3 & .174 & 1.666 & .176 \\
\hline & Within groups & 19.657 & 188 & .105 & & \\
\hline & Total & 20.180 & 191 & & & \\
\hline \multirow{2}{*}{$\begin{array}{l}\text { Preparation and } \\
\text { implementation of the }\end{array}$} & Between groups & 1.683 & 3 & .561 & 5.737 & .001 \\
\hline & Within groups & 18.380 & 188 & .098 & & \\
\hline
\end{tabular}




\begin{tabular}{|c|c|c|c|c|c|c|}
\hline educational plan * & Total & 20.063 & 191 & & & \\
\hline \multirow[t]{3}{*}{ Supporting services } & Between groups & .559 & 3 & .186 & $1.68: 4$ & .172 \\
\hline & Within groups & 20.808 & 188 & .111 & & \\
\hline & Total & 21.367 & 191 & & & \\
\hline \multirow{3}{*}{$\begin{array}{l}\text { Performance of the } \\
\text { administration and } \\
\text { staff * }\end{array}$} & Between groups & .879 & 3 & .293 & 4.23 .4 & .006 \\
\hline & Within groups & 13.009 & 188 & .069 & & \\
\hline & Total & 13.888 & 191 & & & \\
\hline \multirow[t]{3}{*}{ Evaluation (outputs)* } & Between groups & 1.456 & 3 & .485 & 4.169 & .007 \\
\hline & Within groups & 21.883 & 188 & .116 & & \\
\hline & Total & 23.339 & 191 & & & \\
\hline \multirow[t]{3}{*}{ Total* } & Between groups & .636 & 3 & .212 & 3.719 & .012 \\
\hline & Within groups & 10.712 & 188 & .057 & & \\
\hline & Total & 11.347 & 191 & & & \\
\hline
\end{tabular}

Table 13 illustrates statistically significant differences at the level of $(\alpha=0.05)$ due to the geographical region (branch) on the preparation and implementation of the educational plan, performance of the administration and staff, evaluation (outputs), and the tool. However, there are no statistically significant differences on the other domains. To depict the source of significance of these differences, post-hoc comparisons (Scheffe's method) were made (table 14).

Table 14. Post-hoc comparisons (Scheffe's method) of the geographical region (branch) of the services provided to the children with cerebral palsy from the guardians' perspective

\begin{tabular}{|c|c|c|c|c|c|c|}
\hline & $\begin{array}{l}\text { Geographical region } \\
\text { (branch) }\end{array}$ & $\begin{array}{l}\text { Arithmetic } \\
\text { means }\end{array}$ & $\begin{array}{l}\text { Central } \\
\text { region }\end{array}$ & $\begin{array}{l}\text { Western } \\
\text { region }\end{array}$ & $\begin{array}{l}\text { Northern } \\
\text { region }\end{array}$ & $\begin{array}{l}\text { Southern } \\
\text { region }\end{array}$ \\
\hline \multirow{4}{*}{$\begin{array}{l}\text { Preparation and } \\
\text { implementation of } \\
\text { the educational plan }\end{array}$} & Central region & .79 & & & & \\
\hline & Western region & .61 & $.18^{*}$ & & & \\
\hline & Northern region & .72 & .07 & .11 & & \\
\hline & Southern region & .85 & .06 & $.24^{*}$ & .13 & \\
\hline \multirow{4}{*}{$\begin{array}{l}\text { Performance of the } \\
\text { administration and } \\
\text { staff }\end{array}$} & Central region & .97 & & & & \\
\hline & Western region & .79 & $.19^{*}$ & & & \\
\hline & Northern region & .84 & .13 & .05 & & \\
\hline & Southern region & .85 & .13 & .06 & .01 & \\
\hline \multirow[t]{2}{*}{ Evaluation (outputs) } & Central region & .79 & & & & \\
\hline & Western region & .64 & .14 & & & \\
\hline
\end{tabular}




\section{Macrothink $\Lambda$ Institutem}

\begin{tabular}{|c|c|c|c|c|c|}
\hline & Northern region & .58 & .21 & .06 & \\
\hline & Southern region & .84 & .06 & $.20^{*}$ & $.26^{*}$ \\
\hline \multirow[t]{4}{*}{ Total } & Central region & .81 & & & \\
\hline & Western region & .67 & $.14^{*}$ & & \\
\hline & Northern region & .69 & .12 & .02 & \\
\hline & Southern region & .77 & .04 & .11 & .08 \\
\hline
\end{tabular}

* Significant at the significance level of $(\alpha=0.05)$.

Table 14 shows that:

- There are statistically significant differences in the preparation and implementation of the educational plan $(\alpha=0.05)$ between the Western region and the Central and Southern regions, favoring the Central and Southern regions. Literature did not make comparisons in terms of the services provided to the children of the Association of Disabled Children.

- There are statistically significant differences in the performance of the administration and staff $(\alpha=0.05)$ between the Western and Central regions in favor of the Central region. The services provided in King Fahd Center (Central region) are comprehensive and integrated compared to Jeddah center (Western region). A multi-disciplinary team provides the services at King Fahd Center for five hours daily. Additionally, the service providers at King Fahd Center are more efficient than their peers at Jeddah center.

- There are statistically significant differences in evaluation (outputs) $(\alpha=0.05)$ between the Southern region and the Western and Northern regions, favoring the Southern region.

This result matches the results of Alghaliat (2008) in Jordan, reporting that there are statistically significant differences according to the geographical region.

Question III. Do the families' perspectives of the reality of the provided services differ according to the educational level of the parents, average monthly income, and number of years for receiving the associations 'services?

In order to answer this question, the arithmetic means and standard deviations of the services provided to the children with cerebral palsy from the guardian's perspective according to the academic qualification of the father, academic qualification of the mother, average monthly income, and number of years for receiving the associations' services were estimated, as shown in Table 15.

Table 15. Arithmetic means and standard deviations of the services provided to the children with cerebral palsy from the guardian's perspective according to the academic qualification of the father, academic qualification of the mother, average monthly income, and number of years for receiving the associations' services

\begin{tabular}{ccccc}
\hline Variable & Categories & Arithmetic means & Standard deviations & Number \\
\hline Academic & Less than secondary & 0.76 & 0.190 & 23 \\
\hline
\end{tabular}




\begin{tabular}{|c|c|c|c|c|}
\hline $\begin{array}{c}\text { qualification of the } \\
\text { father }\end{array}$ & Secondary and more & 0.70 & 0.250 & 169 \\
\hline Academic & Less than secondary & 0.73 & 0.225 & 31 \\
\hline $\begin{array}{c}\text { qualification of the } \\
\text { mother }\end{array}$ & Secondary and more & 0.71 & 0.248 & 161 \\
\hline Average monthly & SR 9, 000 and less & 0.72 & 0.246 & 109 \\
\hline income & SR 9,000 and more & 0.69 & 0.241 & 83 \\
\hline Number of years & One & 0.76 & 0.217 & 41 \\
\hline for receiving the & Two & 0.74 & 0.189 & 40 \\
\hline associations' & Three & 0.67 & 0.267 & 49 \\
\hline services & Four and more & 0.68 & 0.268 & 62 \\
\hline
\end{tabular}

Table 15 illustrates an apparent difference in the arithmetic means and standard deviations of the services provided to the children with cerebral palsy from the guardians' perspective based on the academic qualification of the father, academic qualification of the mother, average monthly income, and number of years for receiving the associations' services. To estimate the statistically significant differences among the means, ANOVA was utilizedl, as shown in Table 16.

Table 17. Results of ANOVA of the impact of the academic qualification of the father, academic qualification of the mother, average monthly income, and number of years for receiving the associations' services from the guardians' perspective

\begin{tabular}{llll}
\hline Source of variance & $\begin{array}{l}\text { Freedom } \\
\text { degree }\end{array}$ & F- Value & Statistical Significance \\
\hline Academic qualification of the father & 1 & 0.335 & 0.564 \\
Academic qualification of the mother & 1 & 0.041 & 0.840 \\
Average monthly income & 1 & 0.434 & 0.511 \\
Number of years for receiving the associations' services & 3 & 1.374 & 0.252 \\
\hline
\end{tabular}

Table 16 shows that there were statistically significant differences at the level of $(\alpha=0.05)$ or less with the responses of the participants with any variables in terms of the perceptions of the families with the reality of the services provided to the children with cerebral palsy. This illustrates that the services provided by the association consider the needs of the children with special needs and their families despite the differences of sex and academic qualification.

Aloteby (2013) reported significant differences between the illiterate, literate, primary certificate holders of the guardians and those with university degrees. Alghaliat (2008) and Alfawaeer (2013) reported no differences due to the different sex of the child. 


\section{Discussion}

The responses were analyzed by estimating the arithmetic means and standard deviations of the services offered to children with cerebral palsy from the guardians' perspective at the item and domain levels.

Table 5 shows that the services related to the administration and staff services were rated first. However, when considering the regions, there were significant differences at the level of the services. While the Western region was ranked last, the Central region was ranked first where the capital is located because there are adequate competencies, close services, availability of centers offering services, abundance of transportation, and near populated areas.

Diagnosis and evaluation services were ranked second with an agreement degree of (0.72). Additionally, there were no significant differences due to region because the staff of all branches are aware of such type of services. This result differs from the results of Alghaliat (2008).

Regarding the domains of intervention and referral, the preparation and implementation of the educational plan, and evaluation (outputs), the services were rated medium (0.69). There were statistically significant differences between the means of the preparation and implementation of the educational plan and evaluation (outputs) due to the geographical region in the Central and Western regions favoring the Central region. Consequently, more attention shall be paid to the relevant services and following-up the centers of the Western region for development and improvement.

The (supporting services) domain was ranked last and rated (0.65). There were no differences due to the geographical region, indicating that these services shall be developed in all or most of the regions. This might result because other non-governmental institutions play a part in offering such services in large cities only.

The (number of social workers to children) was ranked last, indicating clearly the need to increase the number of social workers at the different centers. Such need differs from a region to another, where the Western region is the highest. This might be due to the higher availability of social workers in cities and availability of special education departments at the colleges of teacher preparation, helping increase the number of specialists.

Generally, except for the Central region, the services should be developed, especially in the Western region because the responses of families suggest a critical need to improve the services provided to the children with cerebral palsy.

Furthermore, the distribution of the services provided to children ranged from medium to high because of the ability and role of the association to offer adequate services that help the children with disabilities overcome this stage. Because the association adequately follows up and monitor the performance of its branches, interest is paid to this category and increases the quality of the services provided to the children. Additionally, the association, with its various branches, is able to earn the trust of the families of the children as they feel that the children are paid adequate care and they feel satisfied with the availability of the services offered. This result agrees with the result of Alfawaeer (2013) and Livingstone (2008), but it differs from the results of Wang et al. (2014) that reported the dissatisfaction of the parents of children with cerebral palsy with the services provided to their children. 


\section{MInstitute Macrothink $^{m}$}

In general, from $(0.20)$ to $(0.35)$ of the participants were not satisfied with the services provided to children. Therefore, all the services in all regions must be improved.

Based on its results, the study suggests that the families of children with cerebral palsy shall be surveyed when developing the offered programs because they are key partners and their opinions are effective to define the aspects of development. Further studies shall be conducted on the population with other variables that may affect the satisfaction of the families with the services provided to the children, including cooperation between the guardians and the association, quality of the curricula, national identity and cultural values, quality of the buildings and facilities, satisfaction of the families with the website of the association, and utilizing social media to interact with the families. Additionally, some studies shall be conducted considering the satisfaction of the service receivers of those with cerebral palsy.

\section{Recommendations}

The study recommends:

- Introducing the objectives of and services provided by the associations to the guardians.

- Activating the role of the trustee boards to introduce the workshops and training offered to the children to the parents.

- Circulating the successful experience of the association by establishing branches in all Saudi provinces in order to serve the largest number of children with disabilities.

- Conducting qualitative studies and researches to provide authentic information on the families' perspective.

- Investigating the similarities between the reality of services and what shall be offered to the children.

- Conducting similar studies to inspect the perspectives of other relevant groups, including teachers, administrators, and supervisors.

\section{References}

Abdulla, H., Hammoda, S., Almohammady, A., Alrashedy, K., \& Alnajjar, H. (2009). Special education: Reference book. Jeddah: Al-Shegrey for Publishing \& Information.

Abuallam, R. (2010). Methods of research. Cairo: Universities Publishing Dar.

Ahmed, S., \& Mostafa, D. (2014). Introduction to special education. Riyadh: Alrashid Bookstore.

Alazza, S. (2001). Special education for those with the visual, auditory, and motor disabilities. Amman, Jordan: Dar Althaqafa.

Alayed, W. (2012). The satisfaction of the guardians with the services offered to students with learning disabilities. Journal of Human and Administrative Sciences, 1, 183-227.

Alfawaeer, A. (2013). Evaluating early intervention services of children with special needs in Oman. Journal of Arab Children, 65.

Alghaliat, A. (2008). Evaluation of health and educational services offered to cerebral palsy children and constructing strategy to establish a center for vocational guidance of cerebral palsy people in Jordan (Ph.D. dissertation). Amman Arab University, Jordan.

Alhazemy, A. (2009). The needs of the guardians of intellectually disabled students and their 
relationship to some factors (MA. thesis). King Saud University.

Alkhatib, J. (2003). Cerebral palsy and motor disabilities: Handbook for teachers and parents. Amman: Dar Alfikr for Publishing and Distribution.

Almousa, N. (2008). An overview of special education in Saudi Arabia. UAE, Dubai: Dar AlQalam.

Alnajjar, H. (2014). Evaluating the supporting services provided to the children with learning disabilities at the governmental schools. International Interdisciplinary Journal of Education, $3(2)$.

Aloteby, B. (2007). Family satisfaction with the levels of the services provided to those with special needs by the programs and private institutes of special education in Saudi Arabia. Research Center of the College of Education, King Saud University.

Alqarutey, Y., Alsaratawy, A., \& Alsamady, J. (2013). Introduction to special education. UAE: Dar Al Qalam Publishing \& Distribution.

Alrosan, F. (2015). Psychology of the abnormal children: An introduction to special education. Amman: Dar Alfikr.

Alsaratowy, A., \& Alsamady, J. (2010). Physical disabilities and health impairments. Amman, Jordan: Dar Alfikr.

Alsaree, I. (2014). Evaluating the programs and services provided to the children with mental disability and autism in the light of the Jordanian quality standards. Al Manara Magazine, $20(2 b)$.

Alshakhs, A. \& Aldamaty, A. (2000). Dictionary of special education and rehabilitation of the abnormal. Cairo: Anglo Egyptian Bookshop.

Alwaqfey, R. (2008). Basics of special education. Amman: Dar Juhaina.

Association of Disabled Children (2010). Handbook of special education. Onaiza: ADC.

Downing, J. A. (2004) Related services for students with disabilities: Introduction to the special issue. Intervention in School and Clinic, 39, 195-208. https://doi.org/10.1177/10534512040390040101

Elkhatib, G. (2008). Contemporary special education: Issues and trends. Amman: Dar Wael for Publishing and Distribution.

Hamblin, T., \& Musa, I. (2006). Family- based rehabilitation for children with cerebral palsy: a Kolkata project. Physiotherapy, 92, 55-60. https://doi.org/10.1016/j.physio.2005.09.001

Johnson, J., \& Duffett, A. (2002). When its your own child: A report on special education from the families who use it. New York: Public Agenda.

Kafafy, A. (2009). Family psychology. Amman: Dar Alfikr.

Livingstone, E. (2008). Parental perception of satisfaction and understanding of special education services (Ph.D. dissertation). University of North Texas, Texas.

Robertson. (2006). The influence of the monitoring process on special edlucation services in West Virginia: Principals point of view. Remedial \& Special Education, 26, 281-296.

Siebes, R., Wijnros, L., Ketelaar, M., van Schie, P., Gorter, J., \& Varmeer, A. (2006). Parent participation in pediatric rehabilitation treatment centers in the Netherlands: A parents' 


\section{Macrothink}

International Research in Education

ISSN 2327-5499 2019, Vol. 7, No. 1

viewpoint. Child: Care, Health, and Development, 33(2), 196-205. https://doi.org/10.1111/j.1365-2214.2006.00636.x

UNICEF (2002). Care center for children with disabilities in Jordan.

Wang, M. Petrini, M., \& Guan, Q. (2014). Evaluation of family - centred services from parents of Chinese children with cerebral palsy with the measure of processes of care 20 (MPOC-20). Child care, Health \& Development, 41(3), 408-415. https://doi.org/10.1111/cch.12183

Wehman, T. (1998). Family-centered early intervention services, factors contributing to increased parent involvement \& participation. Focus on Autism \& Other Developmental Disabilities, 13(2). https://doi.org/10.1177/108835769801300203

\section{Copyright Disclaimer}

Copyright reserved by the authors.

This article is an open-access article distributed under the terms and conditions of the Creative Commons Attribution license (http://creativecommons.org/licenses/by/3.0/). 